\title{
The Military and Nation-Building in Nigeria: The General Ibrahim Babangida Regime, 1985-1993
}

\author{
Adewunmi James Falode \\ Department of History and International Studies, Faculty of Arts, Lagos State University, \\ P. M. B 0001 LASU Post Office, Lagos, Nigeria
}

adewunmi.falode@lasu.edu.ng

Keywords: Nigeria, Nation-building, General Babangida, Praetorian mechanism, Military

\begin{abstract}
On August 27, 1985, Major-General Ibrahim Babangida carried-out a coup d'etat against the then military ruler of Nigeria, General Muhammadu Buhari. The main reason for the putsch was the believe that the Buhari regime had no plan to return Nigeria to civilian rule. Apart from this, the country was beset with various nation-building challenges that the junta had no clear-cut answers to. Such challenges include that of corruption, ethnicity, governance and religion. Babangida carried-out his coup ostensibly to return the country to civilian rule, tackle these nation-building challenges and turn Nigeria into a cohesive, functional and viable polity. To achieve these important aims and objectives, Babangida established a transition programme to return Nigeria to civilian rule and used institutional, praetorian and constitutional mechanisms to tackle the country's nationhood challenges. This work is an analysis of the programmes, measures and initiatives that the Babangida regime used to tackle Nigeria's nation-building challenges and prepare the country for eventual return to civilian rule.
\end{abstract}

\section{Introduction}

By the beginning of 1980, it was clear that the civilian rule of Alhaji Shehu Shagari in the Second Republic could not handle the multi-faceted challenges that confronted the Nigerian state. The major ones are those of corruption, governance and mono-commodity. Of particular importance were the issues of corruption and political instability in the Second Republic. The General Muhammadu Buhari regime that toppled the Shagari administration in 1983 advanced the two as the basic reasons. The junta was initially welcomed by the people but because of its high-handedness and draconian decrees, it soon alienated the citizenry. By 1985, it was obvious to the political elites in the country that the Buhari regime had no plan to relinquish political power back to the people in the foreseeable future. The unpopularity of the Buhari regime that was caused by the aloofness and the draconian style of leadership forced the junta to rely on brute force and military diktat to govern Nigeria. The people and the political elites were excluded from the political administration the country. Feeling that the country was tottering at the edge of a precipice, General Ibrahim Badamosi Babangida carried out a putsch against Buhari on the $27^{\text {th }}$ August, 1985. After the success of his coup against Buhari in 1985, Babangida began a political and socio-economic process that he claimed would rescue Nigeria from the vicious of instability that has plagued the country since independence in 1960. Babangida signaled his desire to return the country to democratic rule by establishing a transition to civilian rule program. In restrospect, this was meant to be the administration signature achievement but for the shenanigans of Babangida himself that truncated what would have etched his name in posterity. Babangida's military administration was like no other in Nigeria's political history. The administration took some radical steps and established some programs whose impacts lasted till the dawn of the Fourth Republic in 1999 and beyond. Apart from the fact that the administration regulated and regimented the pace of socio-political and economic development in the country, Babangida also fundamentally altered the face of the country's geographical terrain. This work is an analysis of the military administration of the General Ibrahim Babangida regime in Nigeria between 1985 and 1993. The emphasis of the work is on the different initiatives and programs the administration used in trying to turn the country into a viable, workable and stable entity. 


\section{Theoretical Rationale: Good Governance Theory}

Good Governance Theory (GGT) is the framework that undergirds this work. The theory highlights some basic ideas that a good government, no matter its type, must abide by. Some of these principles are those of accountability, transparency, efficiency, meritocracy, participation and responsiveness [1]. GGT simply states that a workable state can only be created if it has efficient public service, an independent judiciary, a legal framework to enforce contracts and a responsible administration of public funds [2]. Going by the assertion of the World Bank, good governance is predicated on three things in the society: the type of political system (military, totalitarian, dictatorship, communism), the line of authority in the management of social and economic resources and the capability of government to formulate and implement policies [3]. Other essential elements of the GGT are political participation, rule of law, consensus, equity, inclusiveness and effectiveness. The idea here is that the quality of governance can be enhanced by the judicious adoption of this theory. GGT is aimed at achieving efficiency in public service delivery, encouraging competition, privatization, civil service reforms and decentralization [4]. The theory is associated with governing methods and structures in developing countries. The GGT is particularly relevant to Nigeria. Though, not explicitly stated by the Babangida administration, one can say that what it strived to achieve in Nigeria can be conveniently located and interpreted in the GGT. When Babangida became the head of state in 1985, Nigeria was faced with serious nation-building challenges such as that of governance, corruption, transparency and democracy. In order to get Nigeria out of the political morass that it seemed to be perpetually stuck in, Babangida decided to make governance to be more opened and attuned to the people. What one notices at the beginning of his administration was the desire to create an inclusive political system, based on meritocracy, that is open to every citizen within the country. The administration also strived to entrench such concepts as accountability, transparecncy, responsibility, privatization and an effective and efficient bureaucracy within the Nigerian political and social space. All these are in line with the principles and tenets of the GGT. Had the administration steadfastly adhered to the key principle of implementation of governmental policies, which is tied to the idea of political will, Nigeria would have emerged a better and stronger political entity post-Babangida regime.

\section{Conceptual Clarification}

The authors have discovered in the course of the research that the different rulers in Nigeria made use of conceptual, praetorian, institutional and constitutional mechanisms in the country's nation-building process. The use of these mechanisms, sometimes individually or in combination, was noticeable in the country's nation-building process. These mechanisms were used by the state to achieve the principle objectives of the GGT. Institutional mechanism is the creation and use of specific organizations to tackle particular nation-building challenges. For instance, Olusegun Obasanjo's administration made use of the institutional mechanism to tackle specific challenges of nation-building between 1999 and 2007. This was the rationale behind the formation of the Economic and Financial Crimes Commission (EFCC) in 2003. It was an institutional response meant to tackle the challenge of corruption [5]. General Yakubu Gowon's establishment of the National Youth Service Corps (NYSC) in 1973 was another institutional program meant to help the nation-building process in Nigeria. Other administrations adopted the constitutional mechanism to overcome some aspects of Nigeria's nation-building challenges. Constitutional mechanism is the use of specific provisions in the Nigerian Constitution to address specific nation-building challenges. When there are no such provisions that can tackle specific challenges, the mechanism allow for the use of amendments to the constitution to make it relevant to the particular challenge. This, for example, was the rationale behind the insertion of the federal character principle and principle of fiscal federalism into the 1979 Nigerian Constitution by General Olusegun Obasanjo's regime in 1979 [6]. This insertion was done, it must be noted, to ensure that all the ethnic groups are represented at the centre and to also ensure the equitable distribution of federal resources. 
Praetorian mechanism was the favoured tool of the different military administrations that ruled Nigeria from 1967 to 1999 . This tool involved the use of decrees and edicts to tackle Nigeria's nationbuilding challenges. For example, Major General Aguiyi Ironsi used decrees 33 and 34 of 1966 to turn Nigeria into a unitary state [7]. This was done to tackle the problem of unity in the country's nation-building process. General Yakubu Gowon used the Enterprise Promotion decree No. 4 of 1972 to tackle the challenge of economic insufficiency. And, General Ibrahim Babangida used decree to establish Mass Mobilization for Self Reliance, Economic Recovery and Social Justice (MAMSER) in 1987 [8]. MAMSER was designed to make Nigeria socio- economically and politically viable. Conceptual mechanism the use of targeted ideas, precept, norms, intellection and principles in Nigeria's democratization process. Such concepts include transparency, governance, accountability and rule of law. It is the preference of civil society groups (CSGs) in resolving Nigeria's nation building challenges. In contrast to the vertical approach adopted by the state in Nigeria, CSGs adopted the horizontal approach to tackle Nigeria's nation-building challenges during the period. This approach fostered interactions and the exchange and dissemination of ideas across the socio-cultural and political spectrum of Nigeria. However, some of the military and civilian rulers also made use the mechanism to tackle specific nation-building challenges that confronted them.

\section{The Babangida Regime: An Overview}

On August 27, 1985, Buhari was overthrown in a palace coup staged by Major General Ibrahim Badamosi Babangida. The new military regime cited several factors as justification for the coup. These includes Buhari's inability to bring the economy under control; his dictatorial tendencies that had resulted in a poor human rights record; his failure to establish a transition to civilian rule program; and his refusal to involve his colleagues in the decision-making process of his regime [9]. In order to generate credibility for the new regime, Babangida took a more conciliatory approach to governance than had Buhari [10]. Babangida opened investigations into human rights abuses perpetrated by the Buhari regime and overturned the jail sentences of many of those convicted under his predecessor's regime. Babangida repealed most of the draconian decrees, especially those that Buhari used in gaggling the press between 1983 and 1985. Babangida encouraged public debate on issues pertaining to the governance of Nigeria. In addition, Babangida took the title 'president', a first by any military ruler, rather than use the traditional title 'head of state'. This was done to indicate that he served as chief executive in the new dispensation and to provide the needed democratic legitimation for his tenure [11]. Babangida restructured and reconstituted key organs of government. These included the change in the names of the Supreme Military Council (SMC) to Armed Forces Ruling Council (AFRC) and that of the chief of staff to Chief of General Staff (CGS) [12]. He further expanded the federal character principle in the composition of key organs of government. This last act was done to redress the North-South imbalance created by the Buhari regime.

Through this act, Babangida ensured that none of the three major ethno-linguistic groups in the country could claim any kind of dominance in the makeup of the AFRC. The Presidential Advisory Committee (PAC) was one of the new structures created by the regime to serve as its think-tank. The PAC, established in 1985, consisted mainly of academics who were responsible for formulating and monitoring most of the economic and political policies of the regime [13]. To consolidate its populism, the regime, at the initial stage, adopted a participatory and public-responsive approach to decision-making on crucial issues of national significance [14]. For example, this was the approach Babangida adopted over the IMF/World Bank SAP issue that confronted the regime in 1985. Instead of unilaterally taking the IMF loan, which would have ushered in IMF-inspired SAP for the country, Babangida threw it open and made it into a 'plebiscite' [15]. Nigerians voted against the IMF loan and this made Babangida to evolve a 'home-grown' version of SAP in October 1985 to tackle Nigeria's challenge of aurtarky.

From early 1986, after the initial period of relaxation and debate, the Babangida's regime came under sustained pressure from groups that were opposed to its programs of political and economic reforms. The firm resistance the regime encountered brought out its authoritarian and dictatorial tendency. The main opposition to the regime's authority was spearheaded by the NLC, students and 
university teachers. It has been argued that it was the repressive imperative of SAP implementation that was responsible for the authoritarian posture the regime adopted from the late 1980s [16]. Between 1985 and 1990, the regime uncovered and averted two coups attempt. The first was carried out in December 1985 by General Mamman Vatsa, minister for the Federal Capital Territory with several other officers and men. The plotters were said to be dissatisfied with some of the regime's economic policies and its liberal human rights posture, among other things. Vasta and some of his co-conspirators were executed on March 5, 1986 after being convicted by a military tribunal. The second coup attempt was carried-out in April 1990. This was also put down by the Babangida regime. By 1987, due to the increasing unrest and riots, the regime turned on the NLC, students, ASUU and the Nigerian Press. It was during this period that Dele Giwa, the editor of Newswatch, was killed. Major newspapers in Nigeria, such as The Guardian, Punch, Vanguard and Concord also experienced closure during this period. Religious riots, conflicts and tensions were also rife during Babangida's regime. The challenge of religion became an important problem for the regime when the issues of membership of the Organisation of Islamic Conference (OIC) and that of Sharia brought Nigeria to the brink of a major religious war. In 1986, without consultation or debate with even members of his AFRC, not to talk of the citizens, Babangida made Nigeria a member of the OIC. The move sparked widespread condemnation in the southern part of the country. Christian leaders from the region protested and demanded the immediate withdrawal of Nigeria from the OLC. They based their objections on the fact that Nigeria was a secular state and as such, it has no business being a full member of a religious organization. The Supreme Council For Islamic Affairs (SCIA) in Nigeria was adamant and insisted on Nigeria's continued membership of the OIC. Babangida had to eventually set up a committee, under Colonel John Shagaya, to try and resolve the controversy.

The centerpiece of Babangida's regime was the transition to civilian rule program. From the inception of his regime in 1985, Babangida had announced that the creation of a viable transition program was a major goal. This assertion conferred an important modicum of political capital on his regime among the Nigerian public and CSGs. Indeed, all other policies of the regime such as administrative reforms, mass mobilization, economic policies and grassroots development were all meant to be an integral parts of the transition process. The transition programs of the regime were designed to ensure the birth of the Third Republic on the one hand; and to create a viable, cohesive, functional and democratic Nigeria, at the other extreme. Babangida established a body, the Political Bureau, which among other things, drew up a comprehensive timetable for a transition to civilian rule program [17]. The Political Bureau submitted its report in March 1987, and among other recommendations, stated that the transition period will extend from 1990 to 1992 . But this date was later pushed back to January 2, 1993 and finally to August 27, 1993 [18]. This vacillations was noticeable throughout the different phases of the transition process. Babangida consistently manipulated the transition process by moving timelines, amending procedures and frequently banning and unbanning politicians and government officials during the transition process. He justified his frequent interference on the exigencies of the political process in Nigeria. That is, to create a semblance of stability and continuity in the face of corruption and other socio-economic ills. However, the real reasons for his vacillations became clear towards the end of his regime in 1993. Babangida never planned to give legitimate authority back to the civilians. He was interested in transmuting into a civilian president, or at the least, extends the military's hold on power. The chicanery of such organization as the Association for Better Nigeria (ABN), which was a front for the regime, gave credence to this assertion.

It should be pointed out that Babangida's transition program had social and economic dimensions. Some programs were established to address the social welfare and life chances of the majority of the citizens. These included the Directorate of Foods, Roads and Rural Infrastructural (DFRRI), National Directorate of Employment (NDE) and Peoples Bank. The economics aspect fell under the IMF and World Bank-sponsored SAP. An important stage in the transition process was the formation and registration of political parties. The regime, through the National Electoral Commission (NEC) it established, set stringent guidelines for political parties that wished to participate in the Third Republic. As part of the conditionalities, political parties were expected to 
present the passport photographs of all registered members. Political parties were further expected to establish in all the capitals of states in the federation well-manned and functioning offices. Thirteen political associations applied for recognition. ANPP, Ideal People's Party (IPP), Liberal Convention (LC), National Unity Party (NUP), Nigeria Labour Party (NLP), Nigerian National Congress (NNC), Nigerian People's Welfare Party (NPWP), Patriotic Nigerian Party (PNP), People's Front of Nigeria (PFN), People's Patriotic Party (PPP), People's Solidarity Party (PSP), Republication Party of Nigeria (RPN) and United Nigeria Democratic (UNDP). The thirteen political associations were eventually whittled down to six by NEC. However, none of the six associations was approved for registration as political parties by the AFRC. The AFRC accused the political associations, among other things, of being formed along ethno-regional and religious lines and that some of them were reincarnations of the political parties of the First and Second Republics. The AFRC then went ahead to establish two grassroots political parties in 1989, the SDP and NRC. These were two statesponsored political parties that the regime recognized as being legitimately responsible for carryingout political activities in the Third Republic. Thus, rather than use the transition program to put in place structures that would promote an enduring democracy in the Third Republic, the transition became a tool for promoting Babangida's personal rule. Babangida was actively aided by NEC in this endeavour. The NEC, with Babangida's approval, constantly tinkered with the electoral rules and elections timetable to make it impossible for the recognized political parties to function optimally.

In 1991, Babangida created nine new states bringing the total number of states to thirty. These new states participated in the elections to states assemblies, governorships, and the national assembly that took place in 1992. After repeatedly shifting the dates for the presidential elections, the regime in early 1993 cleared two candidates to run in the presidential elections. Chief M.K.O Abiola was cleared and nominated as the SDP presidential candidate; while Bashir Tofa was nominated for the NRC. The presidential elections finally took place on June 12, 1993. Chief Abiola, the SDP candidate, won the presidential election. Faced with the prospect of finally having to relinquish power, Babangida annulled the election result on June 23. The resulting violence from the annulment, and the general climate of anarchy and insecurity this created, forced Babangida to hurriedly step aside. He handed power over to Chief Ernest Shonekan on August 27, 1993. Shonekan then became the head of the Interim National Government (ING) that ruled Nigeria until he was removed by General Sani Abacha.

Having provided the background and a snapshot of the Babangida regime between 1985 and 1993, the subsequent parts of the paper will be devoted to the analysis of the different mechanisms the administration used in trying to achieve the basic principles in the GGT for the Nigerian state.

\section{The Institutional Mechanism used by the Babangida Regime in the Nation-Building Process}

In tackling the various socio-political and economic challenges that confronted Nigeria between 1985 and 1993, the state created some specific institutions. The following are the specific programs and initiatives created by the state through the use of the institutional mechanisms to tackle the nationbuilding challenges that confronted Nigeria:

The Political Bureau

Structural Adjustment Program (SAP)

Mass Mobilization for Social Justice and Economic Recovery (MAMSER)

National Electoral Commission (NEC)

\section{The Political Bureau, 1986 - 1987}

The decision to establish the Political Bureau was contained in the 1986 Budget Speech of President Babangida. The Bureau was subsequently inaugurated by the president on 13 January, 1986. The establishment of the Political Bureau between September and December 1985 marked the highpoint of the administration's attempt to define and chart the pathways to democratic consolidation in Nigeria. The Political Bureau was created, among other things, to provide the intellectual and practical institutional framework that will be the basis for viable and functional political structures in 
the Third Republic. This important idea was amplified by president Babangida at the inauguration of the Bureau in 1986 [19]. The president noted the important link between the economic, political and socio-cultural dimensions of development and as a further measure tasked the Bureau to ensure that the socio-economic and political challenges that afflicted the First and Second Republics were avoided in the Third republic. In summary, the Political Bureau had the following terms of reference [20]:

(i) To stimulate, guide, and coordinate national political debate through organizing grassroots participation and mobilizing the broad masses of people in the quest for a new political order.

(ii) To collate, analyse and summarize the view expressed in the course of the debate.

(iii) To review Nigeria's political history and identify the problems with a view to making recommendations for solving and coping with the problems.

(iv) To work out a basic philosophy of government for Nigeria;

(v) To prepare a blueprint for a future political model or models for the country;

(vi) To provide a time sequence for political transition by 1990.

The Bureau itself identified thirty main issues. Some of these are: a philosophy of government for the future, a viable popular and genuinely democratic political system, human rights, rural and community development, the armed forces in Nigerian politics, federalism, regionalism, statism, nationality and citizenship and the creation of states [21]. The Political Bureau consisted of 17 members and Dr. S.J. Cookey was made the chairman. Other members were Eme O. Awa, Oyeleye Oyediran, Tunde Adeniran and Sam Oyovbaire. In trying to fulfill its mandate, the Bureau members travelled extensively across Nigeria and the PB also encouraged civil society to be involved in its deliberations. The political Bureau submitted its report to the state in March, 1987. The Report of the Political Bureau was divided into three parts. Part I dealt with the background to Nigeria's political experience. It was a comprehensive review of the Nigerian society and political history. Part II dealt with the need for a new political order in Nigeria. Part III dealt with the issues relating to the transition program of the administration.

In its recommendations, the Bureau advocated for a fundamental redefinition of the substructural relations that characterized political behavior in Nigeria [22]. It also recommended a socialist political order to guarantee equitable distribution of resources and a truly democratic political system. Of course, the federal government rejected this recommendation out of hand. Other recommendations are the establishment of a national directorate for social mobilization to foster a new political culture for the nation; the creation of a two-party system, and the establishment of a system of referendum and recall in order to subordinate political authority to popular control.

It is important to remark here that the Report of the Political Bureau was meant to serve as the blueprint, not just for socio-political and economic transformation of Nigeria, but for the transition of the military to civilian rule. What this study has discovered is that the Babangida administration implemented some of the recommendations of the Report and dispensed with others. When the state received the report of the Bureau, the administration set up a nine- member panel, headed by Major-General Paul Omu on March 30, 1987, to deliberate on the Bureau's recommendations. The panel then produced a white paper on the report. It was this white paper that the state now used in implementing some of the recommendations of the Political Bureau's Report. For example, the state accepted the recommendation for the establishment of a two-party political system but rejected the socialist political system for Nigeria. This was what informed the formation of the SDP and NRC in 1989. It rejected a unicameral in favour of a bicameral National Assembly and it rejected the 1990 time-frame set by the Report for the disengagement of the military from politics.

\section{The Structural Adjustment Program, July 1986-1994}

The Structural Adjustment Program (SAP) was introduced by the Babangida's administration to tackle the challenges of autarky and distribution. It must be remarked here that SAP was designed 
and recommended for Nigeria by the International Monetary Fund (IMF) [23]. The primary purpose of a structural adjustment program is to balance a country's accounts and ensure that the value of exports and imports are stable. It typically lasts three to five years and requires many austerity measures. In the case of Nigeria, and in the specific context of the Babangida's transition program, it was meant to be a short-term strategy for attaining the long-term objective of democratic consolidation. The 1986 budget speech by President Babangida on 31 December, 1985 provided the background to the regime's SAP measures. The 1986 budget was designed to usher in "the era of economic reconstruction and self-reliance." The budget was significant because it spelt out, among other things, the desire of Nigeria to balance her imports with exports; to enhance non-oil exports; minimize dependence on imports, and put the economy on a path to steady and balanced growth [24]. Rather than embark on a SAP program based on IMF conditionality that would have guaranteed international credits for the country in her drive to establish a viable and functional economic base, Babangida opted for a SAP devoid of any foreign inputs. In other words, the administration used the 1986 Budget as the bedrock of an informal Structural Adjustment Program for the country [25]. The main features of Babangida's SAP included a plan to strengthen demand management policies, adopt measures to stimulate domestic production, institute market-determined pricing policies and encourage privatization [26].

The core policies of SAP involved measures to correct for the overvaluation of the naira through the setting up of a viable Second-Tier Foreign Exchange Market (SFEM), overcome the observed public sector inefficiencies through improved public expenditure control program and relieve the debt burden [27]. This for example, was what led to the creation of Second-Tier Foreign Exchange Market (SFEM) in 1986, the Directorate of Foods, Roads, and Rural Infrastructure (DFRRI) in 1986 and Foreign Exchange Market (FEM) in 1987. It is interesting to note that the implementation of SAP was tied simultaneously to the political transition program of the regime [28]. Thus, as the political transition programs faltered in the 1990s, SAP also witnessed a sharp reversal in the laudable effects it has been expected to produce on the Nigerian economy. Sadly, SAP collapsed in 1993 and was officially ended by the General Sani Abacha regime in 1994. SAP failed to resolve the challenge of autarky because of the state's inability to adhere to orthodox structural adjustment package. The Babangida government lacked the administrative social base to implement the structural adjustment programme to its logical conclusions. Fiscal and Monetary management, price policies, privatization and financial liberation, were all subject to hesitation, revision or reversal on the side of the state.

\section{Mass Mobilization for Social Justice and Economic Recovery (MAMSER), 1987}

As part of the transition to civilian rule program, the state inaugurated MAMSER for "an effective socialization and political recruitment of the greater majority of the people" [29]. One can aver that MAMSER was instituted by the state to tackle the challenges of governance and corruption. MAMSER was part of the recommendations of the Political Bureau. It was meant to be established along with a socialist form of government. However, the Babangida administration accepted MAMSER but rejected a socialist arrangement for Nigeria. This doomed the program from the outset. A program that was specifically created to be operated under a socialist system of government was implemented under a capitalist system by the state. Babangida's MAMSER sought to turn Nigeria's political culture around through the building of loyalties across cleavages of class, region, religion and ethnic communities. It was meant engineer consensus within diversity, and foster participation and enlightenment within apathy and ignorance.

MAMSER was an arm of Directorate for Social Mobilization (DSM), which was another important socio-political institution established by the Babangida administration. DSM was formed in 1987. MAMSER had two core objectives. The first was the operation food first campaign that sought to mobilize and organize small scale farmers into cooperatives and to link such cooperatives with banks for loans. The second component sought to enhance social justice by channeling grievances to the Public Complaints Commission. MAMSER functioned from 1989 until 1993 when it was scrapped by the Sani Abacha's administration. In retrospect, the MAMSER initiative succeeded in extending the presence of the state into the rural areas. It achieved this through the activities of 
such institutions as "Better Life for Rural Dwellers." It also recorded modest impact in the political sphere through the creation of Centre for Democratic Studies (CDS). The CDS was established in 1989 with the express aim of ensuring the creation and establishment of a viable and functional democratic society. The failure of MAMSER to turn around the socio-political and economic realities in Nigeria could be attributed to, among other factors, lack of political will, enfeeblement of some of its agencies at inception and lack of financial oversight for the agency. This last factor generated massive waste and non-deployment of vital resources where it would have impacted the most [30].

\section{National Electoral Commission (NEC), 1987}

The establishment of NEC in 1987 was an important plank of the transition to civil rule program of the Babangida regime. NEC was created to mid-wife the dawn of a democratic Nigeria. It was established to organize and monitor all elections during the transition from military to civilian rule [31]. The Commission was created to specifically tackle the challenges of democracy and governance in the Third Republic. The NEC consisted of a chairman and eight commissioners. In assessing the impact of the NEC in creating a viable and functional Nigeria, the institution performed creditably well. The commission conducted what had been adjured the freest and fairest elections in Nigeria's contemporary history. It registered the two-state sponsored political parties, SDP and NRC, and conducted federal elections in Nigeria in 1993. The SDP's candidate, Chief Moshood Abiola, won the election but was prevented from being declared the winner by the state. Thus, it was the political shenanigans of the state that prevented NEC from effectively tackling the challenges of governance and democracy.

\section{Constitutional Mechanism Used by the Babangida Regime in the Nation-Building Process}

Babangida's regime used constitutional mechanisms to tackle some of the nation-building challenges that confronted Nigeria between 1985 and 1993. The constitutional mechanisms of the administration targeted the challenges of federalism, ethno-regionalism, democracy and governance. In the course of the research, this researcher has been able to identify that the following constitutional mechanisms were used by the state in the nation-building process:

(i) The Constitutional Review Committee (CRC)

(ii) The Constituent Assembly (CA)

(iii) The Constitutional Drafting Committee (CDC)

(iv) The draft 1989 Constitution

Based on the recommendation of the Political Bureau, the state made the creation of a viable and functional constitution for Nigeria an important plank of its transition program. In September 1987, the Federal Military Government of Nigeria (FMGN) established a forty-six member Constitution Review Committee (CRC) to review the 1979 constitution. The CRC terms of reference include to fashion a viable and functional constitution for Nigeria; to create a pragmatic and useful balance between the public and private sectors for the Nigerian economy in the constitution, to include measures that will insulate the two-party system from the centrifugal pull of ethno-communal and religious pressures and to identify the roles of traditional rulers in a new political dispensation [32]. The CRC submitted its report on February 1988. The FMGN then established a Constituent Assembly (CA) in April 1988 with powers to deliberate on the draft constitution. At the end of its deliberations, the CA submitted the draft constitution to the Armed Forces Ruling Council (AFRC) in 1989. The key amendments and recommendations include: the stipulation of minimum academic qualifications of school certificate for candidates seeking elective office; the establishment of the local governments as a third-tier of government and the prohibition of any government from giving preferential treatment to any particular religion [33]. For example, the stipulation of minimum academic qualifications was designed to make elective position meritocratic. This addendum to the 1989 Constitution was a key feature of political activity during the Fourth Republic. 
After some slight modification, the Babangida regime then promulgated the 1989 constitution on May 1989. The 1989 Constitution was meant to be the medium through which a viable, cohesive and functional democratic polity could be created for Nigeria. Some of the provisions and amendments that were made into the 1989 Constitution were specifically designed to tackle specific nation-building challenges. For example, the process of states and local government's creation was made more difficult. This was contained in the Sections 9 and 10 of the Constitution. This was done, it must be pointed out, to tackle the challenges of ethno-regionalism and federalism. Other innovations of the 1989 Constitution was the establishment of local governments as the third-tier of government with the power to collect money directly from the Federation Account and the institutionalization of the principles of state policy based on democracy, social justice and sovereignty vested in the people. In sum, the constitutional mechanism of the Babangida regime involved two broad critical elements. The first is political engineering by the military, while the second involved modification designed to avoid the controversial sections of the 1979 constitution. That the 1989 constitution failed to fulfill its nation-building role had nothing to do with any inherent weakness of the constitution. The failure was attributable to the lack of political will on the part of the state to fully implement the provisions of the constitution. Significantly, the coup d' etat of General Sani Abacha in 1993 put paid to any salubrious effect the constitution would have had on socio-political and economic development in Nigeria.

\section{The Praetorian Mechanism Used by the Babangida Regime in the Nation-Building Process}

In its nation-building drive, the Babangida regime extensively used military decrees to tackle the challenges of autarky, federalism, democracy, and governance. Over one thousand decrees were issued on socio-economic and political matters by the General Ibrahim Babangida's administration. In tackling the challenges of federalism, the state used the praetorian mechanism to increase the number of states in Nigeria from 19 to 21 and then 30 between 1986 and 1991, respectively. This was done to create a more ethnically-balanced federalism and to also nip-in the bud the challenge of aggressive ethno-regionalism. In trying to create a stable and functional political environment for the country, the administration used decree No. 27 of 1989 to establish two state-sponsored political parties for the country [34]. These were the SDP and the NRC. It is instructive to point out that it was these two political parties that participated in the 1993 presidential election. This election was meant to usher in the Third Republic. If the election had been allowed to proceed to its logical conclusion, the challenges of governance, democracy, aggressive ethno-regionalism and federalism that plagued the short-lived Third Republic in 1993 would not have occurred. This assertion is based on the fact that the overall winner of the election, Chief M.K.O Abiola, was widely accepted in the different parts of the federation.

The administration used decree No. 12 of 1989 to launch its transition to civilian rule program [35]. This Decree was meant to tackle the bulk of those important socio-economic and political issues hindering Nigeria from emerging as a functional, viable and cohesive democratic society. The decrees specifically targeted the challenges of democracy and federalism. It highlighted in cogent details the step-by-step programs the administration wanted to use to birth the Third Republic in Nigeria. And of course, there was the promulgation Decree of No. 12 of 1989 that brought into existence the 1989 constitution of the federal Republic of Nigeria. In retrospect, the decrees failed to achieve their stated aims of building a viable and functional Nigeria because of the predilection of the state to create retrogressive decrees with every positive ones created. Two good examples of such decrees are decree No. 22 of 1985, National Economic Emergency Power Decree, and decree No. 47 of 1980, the students Union Activities Decree. The first one stifled entrepreneurial development in the country while the second one severely limited the human rights of the citizenry. And of course, Decree 58 of 1993, Constitution of the Federal Republic of Nigeria (suspension) Decree 1993, which suspended and voided the 1989 constitution. 


\section{Findings}

General Ibrahim Babangida ruled Nigeria at a very important period in the country's political history. At the beginning of the administration in 1985, it was confronted with various nation-building challenges. These include those of governance, democracy, ethno-religious conflict, corruption, and autarky. To tackle these challenges, this work has shown that Babangida used Praetorian, Constitutional and Institutional mechanisms. Within each of these mechanisms, Babangida established different programs, initiatives and institutions to resolve the various nation-building challenges that confronted Nigeria. To be fair to the administration, some of those programs, initiatives and institutions would have set Nigeria on an irrevocable path of national resurgence and reinvigoration. For example, MAMSER and the Political Bureau are very laudable initiatives that spurred citizen participation in the political process. However, what became clear from the late 1980s was that Babangida was not ready to relinquish political authority to the political elites with the state. This singular fact doomed the pace of political development in the country and contributed in no small measure to the political, social and religious instability that the country experienced towards the tail end of the Babangida administration. Although, Babangida was interested in birthing democracy, no matter how imperfect, in the country, his desire to transmute from military to civilian head doomed his Nigerian project. This explains why Babangida's transition program 1985 to 1993 is the longest in the country's history.

In the economic sphere, the administration used the same mechanisms to tackle the problems of inefficiency, mono-commoditism, autarky and distribution that seems to be the bane of economic development in the country. Just like it did in the political sphere, the administration tried to regulate and regiment the different facets of the economy. Rather than allow the forces of demand and supply to operate, which would have been true to the tenets of GGT and would have promoted efficiency and effectiveness, Babangida took absolute control of the economy. This amplified and multiplied the deleterious effects of some of the unsound economic practices introduced by the regime. A case in point was the 'indigenous' SAP program the regime introduced without making adequate provisions for the needed socio-economic and political cushions that would have made the people embrace it and make the economic adjustment program a success. From the foregoing, one could see that the administration tried and failed to effectively apply the GGT to turn Nigeria into a workable and viable state. If Babangida had studiously applied the principles and precepts contained in the GGT such as accountable governance, transparency, bureaucratic efficiency and economic sufficiency, the country would have been spared the additional years it took before becoming a democratic state in 1999.

\section{Conclusion}

General Ibrahim Badamosi Babangida governed Nigeria at a very critical junction in the country's political history. Despite the fact that it was a praetorian regime, Babangida tried to reset the trajectory of future political and democratic development in the country. In line with the stated aim of returning the country back to civilian rule after the long military interregnum, Babangida put in place a series of political, social and economic programmes, initiatives, measures and institutions designed to tackle the country's multifaceted nation-building challenges. It can be argued that it was the desire to create a viable, functional and cohesive Nigeria that pushed Babangida to use institutional, constitutional and praetorian mechanisms to resolve the country's nationhood challenges. However, Babangida's failure to adhere strictly to the theory of GGT doomed all his efforts. Had it been that the transition programme was allowed to run its course and Chief Moshood Abiola allowed to become the civilian president in the Third Republic in 1993, Babangida would have placed Nigeria solidly on an irreversible democratic course.

\section{Conflict of Interest}

The author declares that there is no conflict of interest. 


\section{References}

[1] M. Minogue, C. Polidano, D. Hulme (Eds.), Introduction: The analysis of public management and governance, in: M. Minogue, C. Polidano, D. Hulme (Eds.), Beyond the New Political Management: Changing Ideas and Practices in Governance, Edward Elgar Publishing Limited, Cheltenham, 1998.

[2] W.J. Ekundayo, Good governance theory and the quest for good governance in Nigeria, International Journal of Humanities and Social Science. 7(5) (2017) 154-161.

[3] World Bank, Governance: the World's Bank's experience, May 1994. Information on: documents.worldbank.org/curated/en/711471468765285964/pdfmulti0page.pdf.

[4] D. Williams, T. Young, Governance, the World Bank and liberal theory, Political Studies. 42(1) (1994) 84-100. DOI: 10.1111/j.1467-9248.1994.tb01675.x.

[5] E.A. Owolabi, Corruption and financial crimes in Nigeria: Genesis, trend and consequences, (2007). Information http://www.cenbak.org/out/publications/transparency/2007/transparency2007.pdf.

[6] J.A.A. Ayoade, The federal character principle and the search for national integration, in: K. Amuwo et al. (Eds.), Federalism and Political Restructuring in Nigeria, Amuwo 'Kunle Amuwo, Spectrum Books Limited, Ibadan, 2000, pp. 177-178.

[7] S. Iroanusi, The Making of the Fourth Republic, Sam Iroanusi Publications, Lagos 2000, pp. 30-31, 133.

[8] A. Agbaje, Mobilizing for a new political culture, in: L. Diamond, A. K. Kirk-Greene, O. Oyediran (Eds.), Transition Without End, Ibadan: Vantage Publisher, Ibadan, 1997, 147-148.

[9] W.D. Graf, The Nigerian State: Political Economy, State Class and Political System in the PostColonial Era, James Curry, London, 1988, p. 169.

[10] T. Falola, M. Heaton (Eds.), A History of Nigeria, Cambridge University Press, Cambridge, 2008, pp. 217, 225.

[11] T. Olagunju, J. Adele, S. Oyovbaire, Transition to Democracy in Nigeria, 1985-1993, Spectrum Books Limited, Ibadan, 1993, pp. 15, 108, 181, 194.

[12] E.E. Osaghae, Crippled Giant: Nigeria since Independence, C. Hurst \& Co. Publishers Ltd., London, 1998, pp. 191, 195, 217.

[13] T. Forrest, Politics and Economic Development in Nigeria, Westview Press, Oxford, 1993, pp. $48,108,110-111$

[14] C. Legum, Nigeria, in: C. Legum (Ed.), Africa Contemporary Record: Annual Survey and Documents, 1985-1986, Africana, New York, 1987, p. 125.

[15] J.I. Dibua, Collapse of purpose: Ibrahim Babangida, 1985-1993, in: L.A. Nwachukwu, G.N. Uzoigwe (Eds.), Troubled Journey: Nigeria Since the Civil War, University Press of America, Inc., New York: Oxford, 2004, pp. 208, 224.

[16] J.O. Ihonvbere, Nigeria: The Politcs of Adjustment and Democracy, Transaction, New Brunswick, NJ, 1994.

[17] B. Onuoha, Reflections on the transition programmes, in: O. Browne, M.M. Fadakinte (Eds.), Transition Politics in Nigeria, 1970-1999, Malthouse Press Limited, Lagos, 2002, pp. 25, 27.

[18] M. Siollun, Soldiers of Fortune: Nigerian Politics from Buhari to Babangida, 1983-1993, Abuja, 2013.

[19] T. Olagunju, S. Oyovbaire (Eds.), Portrait of a New Nigeria: Selected Speeches of IBB, Vol. 1, Precision Press, London, 1989, pp. 27, 91, 131. 
[20] O. Oyediran, The Political Bureau, in: L. Diamond, A. Kirk-Greene, O. Oyediran (Eds.), Transition without End: Nigerian Politics and Civil Society under Babangida's Regime, Vantage Publishers, Ibadan, 1997, pp. 70, 85, 133.

[21] Federal Government of Nigeria, Report of the Political Bureau, Federal Government Printer, Lagos, 1987, pp. Appendix IXIII (B) and IXIV (A), 203, 233-245.

[22] A. Adeleke, The evolution of party politics in Nigeria, 1914-2000, Monograph Series, University of Lagos, No. 2 (2006) 46-57.

[23] T. Falola, A. Genova, Historical Dictionary of Nigeria, The Scarecrow Press, Inc., Toronto, 2009 , pp. 335.

[24] D. Agbese, Ibrahim Babangida: The Military, Politics and Power in Nigeria, Adonis \& Abbey, Lagos, 2012.

[25] S. Oyovbaire, T. Olagunju (Eds.), Foundations of a New Era: The IBB Era, Precision Press, London, 1989, pp. 35.

[26] J.C. Anyanwu, President Babangida's structural adjustment program and inflation in Nigeria, Journal of Social Development in Africa. 7(1) (1992) 6-7.

[27] S.P. Okongwu, Review and appraisal of the structural adjustment programme, Business Times, Lagos, September 28, 1987.

[28] T. Biersteker, P. Lewis, The rise and fall of structural adjustment in Nigeria, in: L. Diamond, A. Kirk-Greene, O. Oyediran (Eds.), Transition without End: Nigerian Politics and Civil Society under Babangida's Regime, Vantage Publishers, Ibadan, 1997, pp. 340, 362.

[29] A. Agbaje, Mobilizing for a new political culture, in: L. Diamond, A. Kirk-Greene, O. Oyediran (Eds.), Transition without End: Nigerian Politics and Civil Society under Babangida's Regime, Vantage Publishers, Ibadan, 1997, pp. 145, 151-155.

[30] E. Awa, Electoral administration in the early transition, in: L. Diamond, A. Kirk-Greene, O. Oyediran (Eds.), Transition without End: Nigerian Politics and Civil Society under Babangida's Regime, Vantage Publishers, Ibadan, 1997, pp. 127-128.

[31] R.A. Akindele, The constituent assembly, 1988-89, in: L. Diamond, A. Kirk-Greene, O. Oyediran (Eds.), Transition without End: Nigerian Politics and Civil Society under Babangida's Regime, Vantage Publishers, Ibadan, 1997, p. 96.

[32] Federal Republic of Nigeria, Report of the Constitutional Review Committee Containing the Reviewed Constitution, volumes I and II, Federal Government Printers, Lagos, 1988.

[33] S. Adejumobi, Structural adjustment and transition to civil rule programme in Nigeria, 19861993: A shrinking of democratic agenda, in: O. Mimiko (Ed.), Crisis and Contradictions in Nigeria's Democratization Programme: 1986-1993, Stebak Ventures, Akure, 1995, p. 29.

[34] C. Nwankwo, The Nigerian judicial system and human rights. In L. Diamond, A. Kirk-Greene, O. Oyediran (Eds.), Transition without End: Nigerian Politics and Civil Society under Babangida's Regime, Vantage Publishers, Ibadan, 1997, pp. 377, 400-401.

[35] O. Taiwo, Transition and the Law, in: O. Browne, M.M. Fadakinte (Eds.), Transition Politics in Nigeria, 1970-1999, Malthouse Press Limited, Lagos, 2002, p. 203. 